\title{
Evaluasi Kebijakan Pembangunan Infrastruktur Perdesaan (PPIP) di Kecamatan Bolaang Timur Kabupaten Bolaang Mongondow
}

\author{
Abdul R. Dilapanga \\ FIS UNIMA \\ Prodi ilmu Administrasi Negara \\ Tondano, Indonesia \\ abdulrahmandilapanga@unima.ac.id
}

\begin{abstract}
Abstrak-Setiap kebijakan publik yang telah ditetapkan dan diimplementasikan, harus diawasi, dan salah satu mekanisme pengawasan tersebut disebut sebagai "evaluasi kebijakan". Evaluasi kebijakan biasanya ditujukan untuk menilai sejauh mana keefektifan kebijakan publik guna dipertanggungjawabkan kepada publik, sejauh mana tujuan dicapai. Evaluasi diperlukan untuk melihat kesenjangan antara "harapan" dengan "kenyataan".
\end{abstract}

Penelitian ini bertujuan untuk untuk memperoleh temuan lapangan, menganalisis dan menginterpretasikan data lapangan sehingga diperoleh gambaran tentang evaluasi kebijakan PPIP di Kecamatan Bolaang Timur Kabupaten Bolaang Mongondow.

Metode atau pendekatan yang digunakan dalam penelitian ini adalah pendekatan kualitatif, sesuai dengan rumusan masalah dan tujuan penelitian yang bertujuan untuk mengungkap, menganalisis dan menginterpretasikan data lapangan, oleh karena itu digunakan pendekatan kualitatif. Analisis data yang digunakan adalah analisis model interaktif dari Miles dan Huberman.

Berdasarkan hasil penelitian dan pembahasan yang telah diuraikan pada bagian terdahulu, maka dapat ditarik beberapa kesimpulan sebagai berikut:1. Secara keseluruhan ketiga desa sasaran (Bolaang I, Bantik, dan Lolan I) PPIP di Kecamatan Bolaang Timur Kabupaten Bolaang Mongondow, telah mengikuti tahapan-tahapan pelaksanaan pembangunan infrastruktur perdesaan. 2. Masyarakat telah desa diberdayakan dalam pelaksanaan pembangunan melalui OMS,
KPP dan KD artinya keseluruhan proses pelaksanaan kegiatan (tahap persiapan, perencanaan, pelaksanaan, dan pemeliharaan melibatkan peran aktif masyarakat. 3. Fasilitator Masyarakat (FM) yang ditempatkan di Kecamatan Bolaang Timur, telah berperan dalam membimbing dan mengarahkan OMS, KD dan KPP mulai dari tahapan penyiapan dan sosialisasi hingga pelaporan dan penyerahan infrastruktur yang dibangun kepada KPP dan pemerintah desa.4. Kelompok masyarakat miskin dan kaum perempuan benar-benar diberdayakan dan diberikan kesempatan untuk terlibat secara aktif berpartisipasi mulai dari proses perencanaan, pelaksanaan, pengawasan, pemanfaatan dan pemeliharaan dalam pelaksanaan PPIP pada ketiga desa sasaran. 5. Infrastruktur yang dibangun pada ketiga sasaran dapat diterima oleh masyarakat, karena masyarakat telah dilibatkan mulai dari tahapan survey, perencanaan, dan pelaksanaan pembangunan sehingga tepat sasaran sesuai kebutuhan masyarakat desa. 6. Masyarakat pada ketiga desa sasaran merasakan manfaat dengan dibangunnya infrastruktur pada masingmasing desa.7. Secara keseluruhan proses perencanaan oleh masyarakat melalui OMS dan pelaksanaan pembangunan infrastruktur pada ketiga desa sasaran telah dilaksanakan berdasarkan standar dan kriteria yang telah ditentukan. 8. Telah dilakukan penguatan dalam pelaksanaan sistem monitoring dan evaluasi secara terus menerus serta adanya mekanisme penanganan pengaduan masyarakat secara efektif.

Kata-kata kunci: Evaluasi, Kebijakan, Pembangunan, Infrastruktur 


\section{PENDAHULUAN}

Kebijakan Program Pembangunan Infrastruktur Perdesaan (PPIP) merupakan upaya penanggulangan kemiskinan melalui peningkatan akses masyarakat miskin terhadap infrastruktur dasar perdesaan. Program tersebut berbasis masyarakat dengan konsep pemberdayaan masyarakat yang berupaya menciptakan lapangan kerja, meningkatkan kualitas kehidupan, kemandirian dan kesejahteraan masyarakat.

Tujuan PPIP adalah menciptakan dan meningkatkan kualitas kehidupan masyarakat, baik secara individu maupun kelompok sehingga mampu memecahkan berbagai permasalahan terkait kemiskinan dan ketertinggalan yang ada di desanya. Kebijakan PPIP merupakan program berbasis pemberdayaan masyarakat di bawah payung PNPM Mandiri, yang komponen kegiatannya meliputi fasilitasi dan mobilisasi masyarakat sehingga mampu melakukan identifikasi permasalahan ketersediaan dan akses ke infrastruktur dasar, menyusun perencanaan dan melaksanakan pembangunan infrastruktur dasar.

Kecamatan Bolaang Timur sebagai wilayah pemekaran dari Kecamatan Bolaang Kabupaten Bolaang Mongondow, yang meliputi Sembilan desa yaitu: Ambang I, Ambang II, Desa Tadoy, dan Tadoy I, Bolaang dan Bolaang I, Desa Bantik, Lolan dan Lolan I, juga ditetapkan sebagai lokasi PPIP. Sesuai penetapan Kementerian PU, maka pada tahun 2012 PPIP di Kecamatan Bolaang Timur meliputi empat desa yaitu: Tadoy, Tadoy I, Bolaang dan Ambang I, sedangkan untuk tahun anggaran 2013 mencakup tiga desa yaitu: Lolan, Bantik dan Bolaang I.

PPIP sebagai suatu kebijakan mencakup tiga proses kegiatan yaitu formulasi, implementasi dan evaluasi. Program pembangunan infrastruktur yang diusulkan dan dibangun di desa dirumuskan dan ditetapkan melalui musyawarah desa, selanjutnya diimplementasikan sesuai anggaran yang disediakan oleh pemerintah, yaitu masingmasing desa memperoleh alokasi anggaran sebesar Rp. 250.000.000,-.
Dengan tersedianya anggaran, maka proposal yang telah dimusyawarahkan melalui musayawarah desa, dilaksanakan dengan memberdayakan masyarakat yang terdiri dari Organisasi Masyarakat Setempat (OMS), Kelompok Pemanfaat dan Pemelihara (KPP) dan Kader Desa (KD). Sesuai ketentuan pengurus tidak melibatkan perangkat desa dan PNS pada posisi ketua, sekretaris dan bendahara Organisasi Masyarakat Setempat (OMS).

\section{METODE PENELITIAN}

Metode atau pendekatan yang digunakan dalam penelitian ini adalah pendekatan kualitatif, sesuai dengan rumusan masalah dan tujuan penelitian yang bertujuan untuk mengungkap, menganalisis dan menginterpretasikan data lapangan, oleh karena itu digunakan pendekatan kualitatif. Penelitian ini memfokuskan pada proses deskripsi dan pemberian makna atas berbagai faktor yang berhubungan dengan evaluasi program pembangunan infrastruktur perdesaan (PPIP) oleh karena itu penelitian ini menggunakan pendekatan kualitatif. Fokus dalam penelitian kualitatif berkaitan erat dengan masalah yang dirumuskan dan dijadikan acuan dalam penentuan fokus penelitian. Dalam penelitian ini focus utama adalah "Evaluasi Program Pembvangunan Infrastruktur Perdesaan"

Dengan mengacu pada fokus utama tersebut di atas, maka fokus penelitian teraebut selanjutnya dijabarkan dalam dua pertanyaan peneloitian berikut: 1. Bagaimana evaluasi program pembangunan infrastruktur perdesaan (PPIP)di Kecamatan Bolaang Timur Kabupaten Bolaang Mongondow?,

Penelitian ini mengambil lokasi di Kecamatan Bolaang Timur Kabupaten Bolaang Mongondow Provinsi Sulawesi Utara, dengan situs desa Bolaang I, Bantik dan Lolan I. Dipilihnya lokasi ini didasarkan atas pertimbangan bahwa ketiga desa tersebut adalah desa yang ditetapkan sebagai penerima dan pelaksana PPIP tahun 2013.

Dalam penelitian naturalistik yang dijadikan sampel hanyalah sumber yang dapat memberikan 
informasi. Sampel dapat berupa hal, peristiwa, manusia, situasi yang diobservasi (Nasution, 1988:32). Selanjutnya Lofland and Lofland, dalam Moleong (1994:112) mengemukakan "sumber data utama dalam penelitian kualitatif ialah kata-kata, dan tindakan selebihnya adalah data tambahan seperti dokumen dan lain-lain". Sesuai dengan masalah dan fokus dalam penelitian ini, maka sumber data adalah: Key informan, informan awal atau kunci dalam penelitian ini dipilih secara purposif (Stratified Purposive Sampling). Hal ini dilakukan untuk memilih informan yang benar-benar relevan dan benar-benar memahami permasalahan yang diteliti. Sedangkan informan selanjutnya diminta kepada informan awal untuk menunjuk orang lain yang banar-benar dapat memberikan informasi dan kemudian informan ini diminta pula untuk menunjuk informan lain dan seterusnya. Cara ini lazim disebut "snowball sampling" yang dilakukan secara berurutan atau serial. Dalam penelitian ini yang dipandang sebagai informan awal atau key informan adalah Ketua-ketua organisasi masyarakat setempat (OMS), Kader Desa (KD) dan Kelompok Pemanfaat dan Penelihara (KPP) pada ketiga desa sasaran

Dalam penelitian kualitatif, instrument utama adalah peneliti sendiri. Nasution (1988:34) mengemukakan "pada awal penelitian penelitilah alat satu-satunya". Untuk memudahkan dalam pengumpulan data, maka peneliti menggunakan alat bantu berupa pedoman wawancara, field notes, tape recorder, camera foto dan sebagainya.

Teknik pengumpulan data:Wawancara mendalam (In- Depth Interview), teknik ini digunakan untuk menjaring data yang berhubungan dengan : evaluasi program pembangunan infrastruktur (PPIP). Observasi, teknik ini digunakan untuk mengamati kondisi sosial terutama interaksi dan kerja sama antara ketua dan anggota maupun sesama anggota OMS, KD dan KPP maupun hubungan kemitraan dengan pemerintah desa. Dokumentasi, teknik ini digunakan untuk menghimpun berbagai informasi tertulis yang berhubungan kegiatan OMS, KD dan KPP.

Dalam penelitian kualitatif, proses pengumpulan data bergerak dari lapangan empiris dalam upaya membangun teori dari data. Proses pengumpulan data dalam penelitian ini dilakukan sepanjang bulan Agustus sampai dengan Oktober 2014, yang meliputi tiga tahapan yaitu: a) Proses Memasuki Lokasi Penelitian (Getting In). Sebelum memasuki lokasi penelitian terlebih dahulu dilakukan persiapan berupa penyiapan pedoman wawancara, surat ijin penelitian dan alat-alat bantu lainnya. Selanjutnya ketika memasuki lokasi penelitian, peneliti melapor dengan menunjukkan surat ijin penelitian sekaligus memohon ijin untuk melakukan penelitian. b). Ketika Berada di Lokasi Penelitian (Getting Along), ketika dan selama berada di lokasi penelitian, maka sebagai peneliti berupaya memperkenalkan diri, mambaur dan menjalin hubungan yang baik dengan semua pihak di lokasi penelitian,sehingga terjalin hubungan yang harmonis dengan mereka. Mencari informasi/data yang lengkap dan berupaya menangkap makna intisari dari berbagai informasi dan pengamatan yang diperoleh.c). Mengumpulkan Data (Logging the data), selama proses pengumpulan data peneliti telah berupaya mendengar, mengamati serta mencatat semua hal yang didengar dan dilihat, selanjutnya dikategorikan menurut pola, tema dan fokus penelitian. Membuat catatan lapangan, memo (aganda penelitian selanjutnya) dan member check, sertra mengembangkan dan menelusuri kasus-kasus negatif. Pada tahap ini peneliti menggunakan tiga teknik pengumpulan data yaitu wawancara, observasi dan dokumentasi.

Dalam penelitian kualitatif, analisis data dilakukan sejak awal dan sepenjang proses penelitian berlangsung. Analisis data digunakan model analisis interaktif dari Miles dan Huberman (1992:15-20) yaitu: Reduksi Data, Penyajian Data dan Verifikasi. Komponen-komponen analisis data model interaktif.

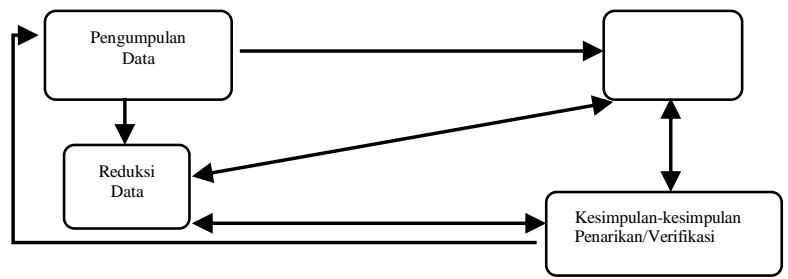


Untuk keabsahan data digunakan empat uji kriteria yang dikemukakan oleh Moleong (1994:173) dan Nasution (1998:105) yaitu: a) derajat kepercayaan, b) keteralihan, c) ketergantungan, d) kepastian.

\section{HASIL PENELITIAN DAN PEMBAHASAN}

Berdasarkan deskripsi data penelitian yang telah disajikan di atas, maka berikut ini dikemukakan hasil penelitian dan pembahasan yang merupakan hasil interpretasi data penelitian sebagai berikut:

1. Secara keseluruhan ketiga desa sasaran (Bolaang I, Bantik, dan Lolan I) PPIP di Kecamatan Bolaang Timur Kabupaten Bolaang Mongondow, telah mngikuti tahapan-tahapan pelaksanaan pembangunan infrastruktur perdesaan.

Sesuai Pedoman pelaksanaan PPIP tahun 2013, bahwa tahapan kegiatan yang dilakukan di itngkat desa secara umum adalah:

a. Tahap penyiapan dan mobilisasi masyarakat, melalui rembug warga, sosialisasi dan Musyawarah Desa I yang dilaksanakan dalam rangka pembentukan OMS, KPP serta pemilihan KD.

b. Tahap Perencanaan Partisipatif dengan kegiatan survey kampong sendiri, Musyawarah Desa II, usul, verifikasi dan finlisasi RKM, serta penyusunan Rencana Tehnis dan Rencana Anggaran Belanja (RAB).

c. Tahap Pelaksanaan Fisik, tahapan ini sesuai pedoman meliputi kegiatan; Musdes III merumuskan rencana pelakanaan pembangunan infrastruktur, pelaksanaan pembangunan infrastuktur dan pengawasannya, serta rembug warga yang membicarakan laporan kegiatan.

d. Tahap Pasca Pelaksanaan Fisik adalah laporan pertanggungjawaban tentang hasil pelaksanaan kegiatan yang disampaikan oleh OMS melalui Musdes IV, serah terima infrastruktur terbangun kepada Pemerintah Desa dan KPP, selanjutnya operasi (pemanfaatan) dan pemeliharaan oleh KPP.

2. Masyarakat desa diberdayakan dalam pelaksanaan pembangunan melalui OMS, KPP dan KD artinya keseluruhan proses pelaksanaan kegiatan (tahap persiapan, perencanaan, pelaksanaan, dan pemeliharaan melibatkan peran aktif masyarakat. Sehingga terjadi peningkatan kapasitas perencanaan dari masyarakat (bottom-up), serta terjadi pula peningkatan kemampuan dalam melaksanakan dan mengendalikan program.

Meningkatnya kapasitas masyarakat dalam perencanaan dan pelaksanaan pembangunan secara partisipatif pada ketiga desa sasaran yang diteliti ditandai dengan telah berfungsinya organisasi masyarakat setempat dengan keterwakilan perempuan. Di samping itu pula telah terlembaga rembug-rembug warga sebagai wujud demokratisasi perencanaan dan pelaksanaan pembangunan.

3. Fasilitator Masyarakat (FM) yang ditempatkan di Kecamatan Bolaang Timur, sangat berperan dalam membimbing dan mengarahkan OMS, KD dan KPP mulai dari tahapan penyiapan dan sosialisasi hingga pelaporan dan penyerahan infrastruktur yang dibangun kepada KPP dan pemerintah desa. Pendampingan oleh FM dalam rangka konsultasi manajemen dan memberikan bimbingan kepada OMS, KPP dan KD pada setiap tahapan kegiatan merupakn suatu keharusan. Setiap tahap kegiatan harus 
didampingi, dibimbing dan diarahkan oleh FM.

Fasilitator masyarakat, merupakan pendamping masyarakat dalam melaksanakan kegiatan PPIP secara langsung di tingkat desa. FM bertugas bertugas memberikan motivasi, bimbingan dan pembinaan kepada OMS, KD dan KPP. Sesuai pedomaan PPIP ditegaskan bahwa setiap tim FM terdiri dari dua orang yaitu; satu orang fasilitator pemberdayaan dan satu orang fasilitator teknik, yang ditugaskan untuk melakukan pendampingan di tiga desa sasaran.

4. Kelompok masyarakat miskin dan kaum perempuan benar-benar diberdayakan dan diberikan kesempatan untuk terlibat secara aktif berpartisipasi mulai dari proses perencanaan, pelaksanaan, pengawasan, pemanfaatan dan pemeliharaan dalam pelaksanaan PPIP pada ketiga desa sasaran.

Sesuai pedoman yang ada PPIP harus berpihak pada orang miskin dan kaum perempuan. Keberpihakan kepada orang miskin memiliki makna bahwa setiap orientasi kegiatan baik dalam proses maupun pemanfaatan hasil pembangunan diupayakan dapat berdampak langsung bagi penduduk miskin dan kaum perempuan.

5. Infrastruktur yang dibangun pada ketiga sasaran dapat diterima oleh masyarakat, karena masyarakat telah dilibatkan mulai dari tahapan survey dan perencanaan, sehingga tepat sasaran sesuai kebutuhan masyarakat desa.

Pendekatan dari bawah (bottom up) yang diterapkan dalam dalam pelaksaanaan PPIP yang melibatkan masyarakat sejak dari awal telah menghasilkan rencna kegiatan masyarakat yang berisi rencana kegiatan pembangunan infrastruktur sesuai kebutuhan masyarakat. Keterlibtan masyarakat sejak awal hingga akhir pelaksanaan kegiatan fisik dan pada akhirnya pemberian tanggung jawab mengoperasikan dan memelihara serta melestarikan infrastruktur terbangun telah menumbuhkan tanggung jawab dan rasa memiliki. Masyarakat menerima PPIP pada ketiga desa sasaran dan tidak ada resistensi (penolakan), karena masyarakat sendiri yang merencanakan, menentukan, melaksanakan, mengawasi dan memanfaatkan infrastruktur yang terbangun.

6. Masyarakat pada ketiga desa sasaran merasakan manfaat dengan dibangunnya infrastruktur pada masing-masing desa.

a. Desa Bolaang I, nelayan di desa tersebut sangat terbantu dengan dibangunnya jalan dan kolam serta tanggul tempat tambatan perahu nelayan sehingga aman dari terjangan ombak, dan memudahkan dalam membongkar/menurunkan hasil tangkapan.

b. Desa Bantik, dengan dibangunnya jalan kebun telah mempermudah akses kendaraan roda dua hingga roda empat (mobil) sampai ke lokasi perkebunan untuk mengangkut hasil-hasil pertanian hingga ke kampong (rumah) hingga siap untuk dipasarkan.

c. Desa Lolan I, dengan dibangunnya jalan penunjang ke lokasi Wisata Pantai Lolan telah memberikan manfaat bagi pemerintah desa, masyarakat desa Lolan I, dan pengunjung ke lolaksi wisata Pantai Lolan yang biasanya selalu mengalami kemacetan terutama pada hari-hari libur (minggu dan hari raya).

Penerima manfaat pembangunan infrastruktur perdesaan adalah masyarakat desa yang namanya termasuk dalam daftar desa sasaran PPIP tahun 2013 yang ditetapkan oleh Menteri Pekerjaan Umum.

7. Secara keseluruhan proses perencanaan oleh masyarakat melalui OMS dan pelaksanaan pembangunan infrastruktur pada ketiga desa sasaran telah dilaksanakan berdasarkan standard an kriteria yang telah ditentukan. Hal ini tercipta karena adanya penguatan dan pelaksanaan sistem monitoring dan evaluasi 
secara terus menerus serta adanya mekanisme penanganan pengaduan masyarakat secara efektif.

Setiap pegaduan terkait pelaksanaan PPIP dicatat, diregistrasi dan didokumentasikan, kemudian didistribusikan sesuai dengan jenjang kewenangan masing-masing subyek, isu dan status pengaduan. Sesuai pedoman PPIP (2013:125) disebutkan bahwa secara umum, inti keluhan masyarakat dikelompokkan menjadi tiga kategori yaitu:

a. Kategori ringan, berupa pengaduan masyarakat yang berkaitan dengan permasalahan

pelanggaran/penyimpangan

administrasi dan prosedur;

b. Kategori sedang, berupa pengaduan masyarakat yang berkaitan dengan permasalahan

pelanggaran/penyimpangan yang salah sasaran (penerima manfaat) dalam pelaksanaan program;

c. Kategori berat, berupa pengaduan masyarakat yang berkaitan dengan permasalahan

pelanggaran/penyimpangan/penyelew engan dana.

Berdasarkan hasil penelitian pada ketiga desa sasaran yang diteliti ternyata pengadun masyarakat pada umumnya berkisar pada kategori ringan yang dapat segera diselesaikan oleh OMS dan KD yang terusmenerus berkoordinasi dengan fasilitator pemberdayaan maupun fasilitator tehnis.

\section{KESIMPULAN}

Berdasarkan hasil penelitian dan pembahasan yang telah diuraikan pada bagian terdahulu, maka dapat ditarik beberapa kesimpulan sebagai berikut:

1. Secara keseluruhan ketiga desa sasaran (Bolaang I, Bantik, dan Lolan I) PPIP di Kecamatan Bolaang Timur Kabupaten Bolaang Mongondow, telah mengikuti tahapan-tahapan pelaksanaan pembangunan infrastruktur perdesaan.

2. Masyarakat telah desa diberdayakan dalam pelaksanaan pembangunan melalui OMS, KPP dan KD artinya keseluruhan proses pelaksanaan kegiatan (tahap persiapan, perencanaan, pelaksanaan, dan pemeliharaan melibatkan peran aktif masyarakat.

3. Fasilitator Masyarakat (FM) yang ditempatkan di Kecamatan Bolaang Timur, telah berperan dalam membimbing dan mengarahkan OMS, KD dan KPP mulai dari tahapan penyiapan dan sosialisasi hingga pelaporan dan penyerahan infrastruktur yang dibangun kepada KPP dan pemerintah desa.

4. Kelompok masyarakat miskin dan kaum perempuan benar-benar diberdayakan dan diberikan kesempatan untuk terlibat secara aktif berpartisipasi mulai dari proses perencanaan, pelaksanaan, pengawasan, pemanfaatan dan pemeliharaan dalam pelaksanaan PPIP pada ketiga desa sasaran.

5. Infrastruktur yang dibangun pada ketiga sasaran dapat diterima oleh masyarakat, karena masyarakat telah dilibatkan mulai dari tahapan survey, perencanaan, dan pelaksanaan pembangunan sehingga tepat sasaran sesuai kebutuhan masyarakat desa.

6. Masyarakat pada ketiga desa sasaran merasakan manfaat dengan dibangunnya infrastruktur pada masing-masing desa.

7. Secara keseluruhan proses perencanaan oleh masyarakat melalui OMS dan pelaksanaan pembangunan infrastruktur pada ketiga desa sasaran telah dilaksanakan berdasarkan standar dan kriteria yang telah ditentukan.

8. Telah dilakukan penguatan dalam pelaksanaan sistem monitoring dan evaluasi secara terus menerus serta adanya mekanisme penanganan pengaduan masyarakat secara efektif. 


\section{REFERENSI}

[1] Abdul Wahab, Solichin, Pengantar Analisis Kebijaksanaan Negara, Rineka Cipta, Jakarta, 1980

[2] ---------, Analisis Kebijaksanaan dari Formulasi ke Implementasi Kebijaksanaan Negara, Bumi Aksara, Jakarta, 1991

[3] --------, Evaluasi Kebijakan Publik, FIA Unibraw kerja sama dengan Penerbit IKIP Malang, 1997

[4] ---------, Analisis Kebijakan Publik Teori dan Aplikasinya,FIA Unibraw, Malang, 1998

[5] Abidin, Said Zainal, Kebijakan Publik, Suara Bebas, Jakarta, 2006

[6] Agustino, Leo, Politik \& Kebijakan Publik, AIPI Bandung-Puslit KP2W Lemlit Unpad, Bandung, 2006

[7] Anderson, James E., Public Policy Making, Holt, Rinehart and Winstoa, USA, 1979

[8] Dunn, William.N, Pengantar Analisis Kebijakan Publik (Penyunting Muhadjir Darwin), Gadjah Mada University Press, Yogyakarta, 2000

[9] FIA Unibraw, Kebijakan Publik dan Pembangunan, IKIP Malang, 1996

[10] Jones, Charles O, Pengantar Kebijakan Publik (Public Policy). Alih Bahasa Nasir Budiman. Jakarta : Penerbit Rajawali, 1991

[11] Miles M, Huberman, Analisis Data Kualitatif, UI Press, Jakarta, 1992

[12] Moleong, L.J., Metodologi Penelitian Kualitatif,(Edisi Revisi), PT Remaja Rosda Karya, Bandung, 2013

[13] Nasution, S., Penelitian Kualitatif Naturalistik Inquiry, Tarsito, Bandung, 1998

[14] Nugroho, Riant, Public Policy, PT Elex Media Komputindo Kelompok Gramedia, Jakarta, 2008

[15] Parsons, Wayne, Public Policy: Pengantar Teori dan Praktik Analisis Kebijakan,(Alih Bahasa Tri Wibawo Budi Santoso),Prenada Media, Jakarta, 2005

[16] Patton, Carl V, dan Sawicki, David.S, Basic Methods of Policy Analysis and Planning. New York: Prentice Hall: Englewood Cliffs, 1986

[17] Patton, Michael Quinn., Metode Evaluasi Kualitatif (terjemahan), Pustaka Pelajar, Yogyakarta, 2006

[18] Rossi, Peter H., Howard E.Freeman, Sonia R. Wright, Evaluation A Systematic Approach,Sage Publications, Beverly Hills, London, 1979

[19] Rusli, Budiman, Kebijakan Publik Membangun Pelayanan Publik Yang Responsif, Hakim Publishing, Bandung, 2013
[20] Rutman, Leonard, Planning Useful Evaluations: Evaluability Assessment (Volume 96),Sage Publications, Beverly Hills, London, 1980

[21] Soeprapto, HR. Riayadi, Evaluasi Kebijakan Publik: Suatu Pendekatan, Universitas Negeri Malang (UM Press), Malang, 2000

[22] Sudarwan, Danim, Pengantar Studi Penelitian Kebijakan,Bumi Aksara, Jakarta, 1997

[23] Tangkilisan, Hesel Nogi S., Evaluasi Kebijakan Publik, Balairung \& Co, Yogyakarta, 2003

[24] Wibawa, Samodra, dkk, Evaluasi Kebijakan Publik, PT RajaGrafindo Persada, Jakarta, 1994

[25] Winarno, Budi, Teori dan Proses; , Kebijakan Publik, Media Pressindo, Yogyakarta, 2002 
